\title{
Community and Collaboration in a Shared Multi-space Office ${ }^{1}$
}

1 Heli Ansio²

Researcher, Finnish Institute of Occupational Health, Finland

I Sari Käpykangas

Researcher, Finnish Institute of Occupational Health, Finland

I Pia Houni

Senior Lecturer, Humak University of Applied Sciences, Finland

\begin{abstract}
Open and shared work environments such as activity-based offices, multi-space offices and coworking spaces have become more popular in recent years. This paper reports the results of a qualitative case study of community and collaboration in a multi-space office shared by six publicly owned companies in Finland. Using interviews $(n=29)$ and participant observation, the study examines how collaboration and community are understood in the six companies, and how they change during an intervention process. We argue that even though a sense of community, collaboration and synergies are expected to arise from sharing an office space, they do not necessarily emerge spontaneously without effort on the part of management.
\end{abstract}

\section{KEYWORDS}

Activity-based office / collaboration / community / coworking / multi-space office / multi-tenant office / shared office

\section{Introduction}

his article presents the results of a case study of a shared office in one of Finland's major cities. The background of this research is related to two current discussions: that on coworking spaces as facilitators of collaboration, knowledge-sharing and serendipitous encounters, and that on workspace changes from cellular offices to openplan and/or activity-based offices.

At its simplest, coworking means independent professionals sharing a workspace. Coworking spaces are shared offices or other workspaces dedicated to serving these professionals. They offer desk space for a fee, but they also often boast an attractive working environment, valuable social contacts, collaboration with other professionals, basic office amenities, 'good coffee and cool parties' (DeGuzman \& Tang 2011; Spinuzzi 2012; Capdevila 2015; Gandini 2015; Moriset 2017). Coworking has increased worldwide after the financial crisis of 2008 and is linked to the precarious condition of

\footnotetext{
${ }^{1}$ You can find this text and its DOI at https://tidsskrift.dk/njwls/index.

${ }^{2}$ Corresponding author: heli.ansio@ttl.fi.
} 
self-employed creative professionals and knowledge workers (Gandini 2015; Moriset 2017). This increase has taken place in the Nordic countries, too. One perspective to this may be that people seek new opportunities to experience feelings of belonging, because working life is fragmented and unsafe. In Finland, for example, the proportions of parttime workers and the self-employed have grown during the 2000s (Sutela \& Pärnänen 2018, pp. 15-17). One important influence in the transition of working life has been the experienced lack of togetherness (Sennett 2012). Coworking spaces may offer one way of fulfilling this need.

Office environments have also changed in the corporate world and public organizations. Changes in office spaces during the last decade are mostly due to the rapid development of portable tools such as laptop computers and mobile phones (De Paoli et al. 2013, pp. 181-182; Morrison \& Macky 2017, p. 103). Another driver affecting the transformation of office environments is the pressure to reduce property costs. Adopting an open-plan design reduces the amount of space per workstation, whereas an activity-based office with a policy of desk-sharing (or hotdesking) increases the number of employees using a single workstation (Kim et al. 2016, pp. 203-204.) Sirola et al. note that in the research literature, activity-based office often refers to an office without assigned desks, whereas multi-space office refers to a similar office in which each employee has a desk of their own. However, many office environments combine different design styles, and do not represent one 'pure' type. Sometimes the concept of combi office is used of workspaces that provide both single rooms and shared workspaces (Sirola et al. 2017, p. 5). All variants of these flexible office spaces have special areas for teamwork, formal meetings, casual encounters, and work that requires intense concentration.

Sankari (2019) uses the term multi-tenant office of offices in which space, facilities and services are offered to multiple tenants. Huwart et al. (2012) distinguish coworking from other types of office-sharing on four principles: 1) Coworking spaces mainly host individuals, not organizations, 2) In coworking spaces, coworkers are not always the same people, 3) Coworking is not only about sharing space but about making people interact, and thus, 4) The objective of coworking is to establish a community, in which people can enjoy synergies. There are several different kinds of coworking spaces; Kojo and Nenonen (2016, pp. 308-309) classify Finnish coworking spaces according to business model (non-profit or for-profit) and level of access for users (public, semi-public or private). However, establishing community and creating synergies between coworkers remain a central aim. (On Finnish coworking spaces, see also Houni \& Ansio 2015; Sankari 2019.)

Jensen (2008) studied relations between market and gift economies in an 'office hotel' in Stockholm and in Copenhagen. Back then, the term coworking was not widely used. Jensen labels the office hotel as a 'social and business experiment'. What was then experimental has now been normalized: the idea that freely giving knowledge and ideas will eventually return as business assets is a basic assumption about the benefits of sharing workspace. This idea of coworking is also adopted by bigger companies that utilize shared and open office spaces to facilitate encounters (Saval 2014, pp. 306-307). Even so, links to the coworking phenomenon are only rarely recognized in the literature concerning new office spaces. Bouncken et al. (2018) refer to corporate coworking in their list of coworking service providers, meaning firms that offer their employees coworking spaces (see also Bouncken \& Reuschl 2018). Jakonen et al. (2017) assert that as a 
practice, coworking lies 'at the centre of changing post-industrial work' and is linked to an 'economy of encounters', in which social interaction becomes a form of production. They analyze the nature of encounters in different kinds of coworking spaces in Finland, Sweden and the US, including an activity-based office of a large corporation. Babapour et al. (2018) refer to coworking in their Swedish case study of a small organization that adopted an activity-based flexible office that accommodated employees from different organizations.

Prior research evidence of the characteristics of shared work environments is mixed. On the one hand, they are seen to provide social support (Gerdenitch et al. 2016), enable learning and innovation (Bouncken \& Reuschl 2018; Capdevila 2015) and create a sense of community (Garrett et al. 2017). On the other hand, they have proven to reduce face-to-face interaction (Bernstein \& Turban 2018) and cooperative behavior between employees, as well as increase distrust and negative interpersonal relationships (Morrison \& Macky 2017). The crucial factor in these differences seems to be the nature of the workspace (and the form of employment of people working in it): Independent professionals in coworking spaces experience social support and community, whereas employees in corporate shared offices may experience distractions and distrust. As we suggested above, collaboration and exchanging ideas nevertheless also seems to be the ideal behind open, flexible office spaces and shared working environments in bigger organizations.

The aim of our study is to contribute to understanding how coworking ideals emerge in multi-tenant work environments of larger public-sector organizations. Our study aims at bridging the gap between coworking research that is often targeted at self-employers and small businesses, and the research of flexible office environments, which mostly concerns bigger organizations. Our study examines how community and collaboration are understood, strived for and constructed in the speech and actions of a work community of six publicly owned companies that share a multi-space office. What do employees working in a shared office think about sharing an office space? What is their conception of the impact of the shared office on collaboration and community?

\section{Theoretical frame}

The most important theoretical concepts of this research are collaboration and community. Spinuzzi et al. (2019) argue that both are at the center of most academic and popular coworking literature: a common claim is that 'coworking is about community, specifically, the collaboration that takes place within communities'. (Spinuzzi et al. 2019, p. 114.) They argue that despite this, both community and collaboration as concepts remain underdefined in the current coworking literature. Spinuzzi et al. apply and adapt Adler and Heckscher's (2006) typology, which builds upon Tönnies's distinction between Gemeinschaft (relationships based on blood relations and personal bonds of loyalty, such as in medieval towns), and Gesellschaft (an artificial construction of an aggregate of individuals who act rationally to maximize their own benefit). Adler and Heckscher add a third form, the 'collaborative community' or Genossenschaft, which emerges when collectives aim for a common object in a cooperative, interdependent way (Adler \& Heckscher 2006; see also Adler 2015). Spinuzzi 
et al. specifically point out that the concept of collaboration is used inconsistently in the coworking literature; its use does not refer to 'incidents in which people colabor on a shared project objective' (Spinuzzi et al. 2019, p. 118). Based on empirical research on coworking spaces, they suggest that actual collaboration on common projects is relatively rare, even in coworking spaces that explicitly proclaim their openness to collaboration.

Most classical sociological writers, such as Durkheim, Weber, Tönnies and Simmel have used the word 'community' to describe a certain togetherness. Anthropologist Anthony P. Cohen (1985) proposed that the word implies two related suggestions: 1) that the members of a group of people have something in common with each other, and that this 2) significantly distinguishes them from members of other groups. 'Community' thus implies both similarity and difference. Cohen focuses on what he sees as an essential 'element which embodies this sense of discrimination'; the idea of a boundary. The consciousness of a community is captured in the perception of its boundaries, which are largely constituted by people in interaction (Cohen 1985, pp. 11-13).

Sankari (2019, p. 3) claims that 'fostering a sense of community is one of the main objectives of many co-working spaces'. According to McMillan and Chavis's (1986) influential theory, a (psychological) sense of community consists of four elements: membership, influence, integration and emotional connection. Membership means a feeling of belonging or a sense of relatedness. Influence is about a bidirectional sense of making a difference to a group, and a group mattering to its members. Integration is characterized by a fulfilment of needs in a way that the individual-group association is rewarding to its members. Finally, an emotional connection is based on a shared history with which the group members identify, and which develops through interaction.

In a context of a work community sharing a new office, we also find it important to consider the sense of individual and collective psychological ownership of the space. Psychological ownership refers to the frame of mind in which a person feels that a property, or part of it, is their own (Pierce et al. 2001). Pierce and Jussila suggest that psychological ownership can also emerge as a group-level phenomenon: Collective psychological ownership means a collective feeling that the target such as an idea, a project or a work space, is collectively ours (Pierce \& Jussila 2010). Psychological ownership is socially constructed and has significant effects on behavior and feelings (Pierce \& Jussila 2010; Pierce et al. 2001). We discuss how the realization of this 'our-ness' - or lack of it - might influence on building community and collaboration in a multi-tenant office space.

\section{Description of the research}

The research at hand was a qualitative case study (Gerring 2007; Yin 2018). Several case studies concerning the work communities that use shared and flexible offices have already been done, also in the Nordic countries (e.g. Jensen 2008; De Paoli et al. 2013; Babapour et al. 2018; Våland \& Georg 2018). However, references to the coworking literature are rare in the existing case study research of activity-based and multi-space offices, and vice versa. 
The office in which the study took place was shared by six municipality-owned companies. The selection of the case organizations was done already in the preparatory phase of the research (see Yin 2018, p. 105). The organizations had moved into the shared office a year before the research activities began. They did knowledge-oriented and service work in the fields of regional development, regional planning, transportation, welfare services, infrastructure, and trade and innovation. When the research and development activities started, the smallest organization had six employees, while the largest had approximately 70 .

The office was in an old industrial building in the center of a large Finnish city. The milieu had connotations to the industrial history of the city, because the building had formerly been the main factory of a major employer in the region. The office space had been renovated for the purposes of knowledge-oriented work. Basically, it was an activity-based or a multi-space office. It was divided by glass walls so that two of the organizations had separate areas, one of which was behind an inner door. Three of the organizations shared a large open-plan space (though divisions had also been made using glass walls). In addition to this were silent spaces, phone booths and cubicles for small meetings, a large recreation area and a conference center. Some organizations practiced hot-desking, while others had fixed desks for each employee.

\section{Data and methods}

As is typical in case studies, we utilized several sources of evidence (Yin 2018, pp. 113-138). A timeline of the data collection is presented in Table 1. The project began with short, half-structured interviews of employees and managing directors $(n=29)$ on the themes of changed work environment, social interaction, collaboration and community. The interviews were conducted one year after the organizations moved into the shared office. The shortest interview was 15 minutes long, while the longest lasted 1 hour. The interviews were voluntary for the participants. The duration of the interviewees' employment at the organizations at the time of the interview ranged from 17 years to a few months. The interviewee's ages varied between 25 and 61. All the directors were interviewed. Two of the organizations had the same CEO (one company being a subsidiary of the other). In one organization, the director was soon to move to another assignment, and the deputy director was taking her place. We interviewed these directors together in a dyadic interview. All the interviews are listed on Table 2 and they form the first data set used in this article.

Table I Timeline of data collection and intervention workshops.

\begin{tabular}{l|l|l|l}
\hline $\begin{array}{l}\text { Collection of } \\
\text { research } \\
\text { material }\end{array}$ & $\begin{array}{l}\text { Research interviews by Authors I and } 2 \\
\text { October 2017-February 2018 }\end{array}$ & $\begin{array}{l}\text { Observation of the evaluation } \\
\text { workshop by Author I } \\
\text { September 2018 }\end{array}$ \\
\hline $\begin{array}{l}\text { Intervention } \\
\text { workshops }\end{array}$ & $\begin{array}{l}\text { Workshop to support } \\
\text { well-being and networking, } \\
\text { facilitated by a psychodramatist } \\
4 \text { times in February-May } \\
2018\end{array}$ & $\begin{array}{l}\text { Coaching workshops for } \\
\text { managing directors, } \\
\text { facilitated by a coach } \\
5 \text { times in February-August } \\
2018\end{array}$ & $\begin{array}{l}\text { Evaluation workshop, } \\
\text { facilitated by Author } 2 \\
\text { September 2018 }\end{array}$ \\
\hline
\end{tabular}


Table 2 Interviewees (data set I) and participants of the evaluation workshop (data set 2).

\begin{tabular}{|c|c|c|c|c|c|}
\hline ID & Gender & $\begin{array}{c}\text { Organization } \\
(1,2,3,4,5 \\
\text { or } 6)\end{array}$ & $\begin{array}{c}\begin{array}{c}\text { Director }=\text { I } \\
\text { Employee } \\
=2\end{array} \\
\end{array}$ & \begin{tabular}{|c|}
$\begin{array}{c}\text { Participation in } \\
\text { the interview } \\
\text { (data set I) }\end{array}$ \\
\end{tabular} & $\begin{array}{c}\text { Participation in } \\
\text { evaluation workshop } \\
\text { (data set } 2)\end{array}$ \\
\hline I & $M$ & $\mathrm{O3}$ & 2 & $x$ & $x$ \\
\hline 2 & $M$ & O3 & 2 & $x$ & $x$ \\
\hline 3 & $M$ & O4 & I & $x$ & \\
\hline 4 & $\mathrm{~F}$ & O4 & 2 & $x$ & \\
\hline 5 & $\mathrm{~F}$ & O4 & 2 & $x$ & \\
\hline 6 & $\mathrm{~F}$ & ○4 & 2 & $x$ & \\
\hline 7 & $\mathrm{~F}$ & $\bigcirc 4$ & 2 & $x$ & \\
\hline 8 & $\mathrm{~F}$ & $\bigcirc 4$ & 2 & $x$ & \\
\hline 9 & $F$ & O4 & 2 & $x$ & $x$ \\
\hline 10 & $\mathrm{~F}$ & $\mathrm{O} 2$ & 1 & $x$ & \\
\hline 11 & $\mathrm{~F}$ & $\mathrm{O} 2$ & 2 & $x$ & $x$ \\
\hline 12 & $\mathrm{~F}$ & $\mathrm{O} 2$ & 2 & $x$ & \\
\hline 13 & $M$ & $\mathrm{O} 2$ & 2 & $x$ & \\
\hline 14 & $M$ & $\mathrm{O} 2$ & 2 & $x$ & \\
\hline 15 & $\mathrm{~F}$ & $\mathrm{O} 2$ & 2 & $x$ & $x$ \\
\hline 16 & $M$ & $\mathrm{O} 2$ & 2 & $x$ & $x$ \\
\hline 17 & $F$ & $\mathrm{O} 2$ & 2 & $x$ & \\
\hline 18 & $\mathrm{~F}$ & $\mathrm{O} 2$ & 2 & $x$ & \\
\hline 19 & $\mathrm{~F}$ & $\mathrm{OI}$ & 2 & $x$ & \\
\hline 20 & $\mathrm{~F}$ & O6 & 2 & $x$ & $x$ \\
\hline 21 & $M$ & O5 & 2 & $x$ & $x$ \\
\hline 22 & $\mathrm{~F}$ & O5 & 2 & $x$ & \\
\hline 23 & $\mathrm{~F}$ & O5 & 2 & $x$ & \\
\hline 24 & $M$ & $\mathrm{O4}$ & 2 & $x$ & $x$ \\
\hline 25 & $\mathrm{~F}$ & O5 & 2 & $x$ & $x$ \\
\hline 26 & $M$ & $\mathrm{O} 2$ & 1 & $x$ & \\
\hline 27 & $M$ & $03 \& 06$ & 1 & $x$ & \\
\hline $\begin{array}{l}28 \& \\
29 \\
\end{array}$ & F\&M & $\mathrm{OI}$ & $\begin{array}{l}\text { I (current \& } \\
\text { upcoming) }\end{array}$ & $x$ & \\
\hline 30 & $\mathrm{~F}$ & $\mathrm{OI}$ & 2 & & $x$ \\
\hline 31 & $\mathrm{~F}$ & $\mathrm{O} 2$ & 2 & & $x$ \\
\hline 32 & $M$ & $\mathrm{O3}$ & 2 & & $x$ \\
\hline 33 & $\mathrm{~F}$ & $\mathrm{O} 2$ & 2 & & $x$ \\
\hline 34 & $M$ & O4 & 2 & & $x$ \\
\hline 35 & $\mathrm{~F}$ & $\mathrm{O3}$ & 2 & & $x$ \\
\hline 36 & $F$ & O5 & 2 & & $X$ \\
\hline 37 & $M$ & $\mathrm{O} 2$ & 2 & & $x$ \\
\hline 38 & $F$ & $\mathrm{O} 2$ & 2 & & $x$ \\
\hline 39 & $M$ & $\mathrm{O} 2$ & 2 & & $x$ \\
\hline
\end{tabular}


After the initial interviews, two professional facilitators (a psychodramatist and a coach) led two series of intervention workshops (see Table 1). Their content was based on the hopes and needs of the employees and managers of the participating organizations. The workshops were voluntary for the employees and directors. All were allowed to use work time for participation.

The two series of intervention workshops were evaluated in an evaluation workshop. The evaluation was based on a new method, which integrates 1) a multi-criteria evaluation framework to evaluate multiple impacts of solutions, and 2) the idea of developmental evaluation to support multi-voiced evaluation and continuous learning. Six dimensions are used to evaluate the impacts of the service innovation (in our study, the impact of the interventions): impacts on the citizen, the employee and the population; and impacts on reputation, integration of technology and services, and economy (Hyytinen et al. 2017; see Figure 1). We used a slightly modified version of the evaluation framework to better capture the situation of the research subjects; for example, we replaced 'the population' dimension by 'the whole work community'.

Figure I Impact dimensions of the evaluation tool (Hyytinen et al. 2017, p. 31 I).

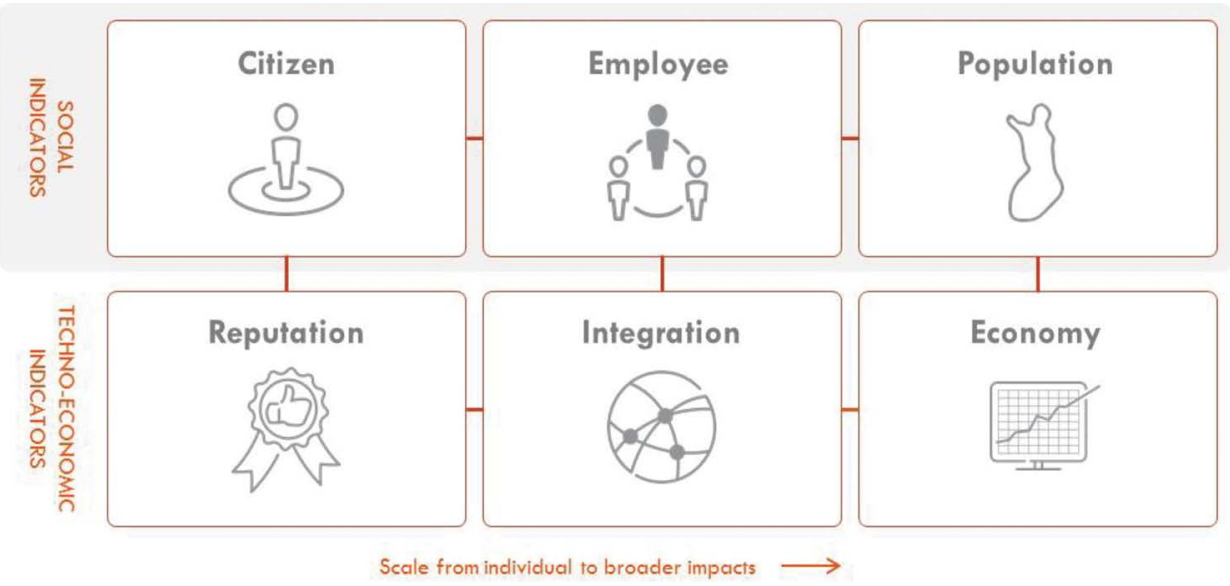

The evaluation workshop started with prepared speeches by pre-selected and instructed participants of the intervention workshops. After this, the participants discussed and evaluated the success of the interventions. The first part of the evaluation workshop was devoted to discussion on the well-being and networking intervention. The second part of the evaluation workshop dealt with the intervention that aimed to develop management and leadership. In total, 20 people attended the evaluation workshop. Table 2 includes the list of participants.

Two of the researchers and authors of this article were present in the evaluation workshop - Author 2 as facilitator, Author 1 as a participant observer (with an emphasis on observation; see O'Reilly 2005, pp. 101-104). The second data set used in this article comprises voice-recorded and transcribed discussion data and observation notes from the evaluation workshop.

In this article, we use the two data sets together to understand how collaboration and community in the office space were conceived in the initial interviews, compared 
to their understanding in the evaluation workshop. The interviews, the discussion data and the observation notes were analyzed using qualitative content analysis. We approached the data in an abductive way, combining a data-driven and concept-driven approach (Graneheim et al. 2017, pp. 30-31). In the first phase of the analysis, we carefully read through the entire interview material. We arranged the transcribed material into tables according to the manifest content of the interviews, condensing the verbal material and including several short citations from the transcriptions. This phase was conducted by the first two authors. We used the categories formed by the tables to further read the material and to make combinations and interpretations to access the latent content. Then, we explored the interview transcriptions considering the research topics (relation to the changed workspace, interaction, collaboration, community). (On the process of content analysis, see Bengtsson 2016; Erlingsson \& Brysiewizc 2017; Graneheim et al. 2017). All the authors took part in the latter phase of the analysis, sharing and discussing the findings to further elaborate the interviews' underlying themes.

The evaluation data were analyzed in the following manner. Author 2 read the observation notes (written by Author 1) and discussion transcription side by side. She coded and categorized the discussion data according to the research topics and themes that also emerged in the interviews. She moved between the observation notes and the discussion transcript, comparing them and focusing the analysis accordingly. During this process, she also paid attention to the ways in which the discussions proceeded. After this phase, we discussed the analysis in the same manner as we had discussed with the interview material.

Finally, we identified temporal phases in the whole data and gave them descriptive names to illustrate the changes in collaboration and community. The phases are 1) Preparation and expectations, 2) Adaptation and 3) Towards working together. The next chapter presents the results in this temporal order.

\section{Results}

\section{Preparation and expectations - why did these organizations create a shared office?}

The first phase consists of interview material that is retrospective in nature; it depicts the expectations and ideals of collaboration and community that influenced the move to the multi-tenant office. The phase includes the justifications for the existence of the shared office.

In the initial interviews, the managing directors were unanimous in their reasons for the move to the shared office. All the companies had the same shareholders: the municipalities of the region. The directors saw that it was in the owners' interests that they worked closely together. This was not a forced move, and for some organizations (Organization 1 and Organization 3), the reason for the move had not even been to find a better place. Pressures to leave the old premises or renovation needs were also reasons in some cases (Organization 2 and Organization 5). Some organizations gained financial benefits, especially the smallest one (Organization 5). According to the interviewees working in the smallest organization, they now enjoyed high-quality 
infrastructure, which they could not have afforded alone as a small organization. One of the organizations was looking for better premises due to indoor air problems (Organization 4).

The directors acknowledged that they also sought their own benefits, and that meeting the shareholders' wishes had not been their only aim. Their own hopes were to gain new perspectives, pleasure and energy from a new shared office. Their expectations were directed at increasing interaction, collaboration and synergy benefits between the organizations.

According to our interpretation, the directors' hopes and expectations are based on two commonly shared ideas of open and flexible workspaces. First, they are related to a fundamental understanding of physical proximity leading to more social interaction, which indeed has strong support in sociological research (Bernstein \& Turban 2018, pp. 1-2). This idea of closeness predicting interaction and even cooperation emerges, for example, in one director's description of straightforward communication between the organizations: 'experts of specific substance areas sit next to each other, regardless of employer' (Interviewee 26). Second, the directors' ideas that a shared office may lead to new perspectives on work, new kinds of collaboration and even unexpected synergy benefits, are common conceptions of the advantages of coworking (and of openplan offices) found in both research literature and media texts. The perceived value of coworking stems from serendipitous encounters, which open and flexible spaces enable (Jakonen et al. 2017, p. 236). Thus, the management shared the presumption than once a shared work environment was established, a new kind of community and new forms of collaboration would emerge spontaneously.

One theme that emerged from the interview material was ownership. Some of the directors expressed psychological ownership of the office space, which originated from the planning period of the office: 'In my opinion I am the owner of these premises because I designed them in the working group' (Interviewee 29). The director of Organization 2 saw himself as the founder of the shared office space solution. He talked about approaching the mayor and asking: 'if it would be reasonable to put these organizations owned by the municipalities into the same "sports center", without any walls even' (Interviewee 26). The directors of Organization 1 and Organization 2 talked about the office space metaphorically as their own 'lands'. One of the directors pointed out that the transfer should have taken place many years earlier and justified his opinion claiming true collaboration between the organizations:

Our organization enables and implements projects in this network. We should have always worked in a shared office with these project partners. Trends have changed in terms of workspaces. Earlier, working in a shared office or open-plan office would have been unheard of. In my genuine opinion, we should have done this many years ago. It could have accelerated certain things and reduced challenges. (Interviewee 3)

Instead, the director of Organizations 3 and 6 had started working in his position after the decisions of the multi-tenant office had already been made. His approach to sharing an office with these partners was more reserved. He saw sharing an office space with the other organizations mainly as a good solution: 'It probably benefits planning work and is useful because of spontaneous encounters'. However, he was also slightly more critical than the directors who were directly involved in the planning period: 
We could also have been located in an office building where the real enterprises and the government organs [for the financing of enterprises] are. That would have been another natural place for us. But in principle this arrangement works ok for us. (Interviewee 27)

According to the directors of Organization 1 and Organization 2, the employees were trained and prepared for the move to the shared office in advance. A planning group was established, and some employees were involved in the design. As Babapour et al. note, 'involving employees, especially in early phases of planning [activity-based flexible offices], can lead to a collective sense of ownership and therefore may minimize rejection of the new system' (Babapour et al. 2018, p. 90). However, some employees we interviewed felt that their voices had not been heard in the process of designing the office space. There had also been fears regarding the shared office, especially of not being able to concentrate on demanding tasks in an open environment. Some employees, especially those who had previously worked in a corridor office, had been suspicious towards the open-plan design at the outset. These employees seemed to lack a sense of psychological ownership of the space, and some lacked any sense of belonging at all. Some of the employees also stated that the management pushed the change through stubbornly. One of them explicitly expressed the opinion that the new office was their managing director's private project, in which the organization's image issues were the primary concern and employee well-being or the fluency of work arrangements secondary.

Like the directors, the employees also acknowledged that presumed synergies between the organizations owned by the municipalities had been reasons for moving to the shared office. However, their perceptions of the justifications for the multi-tenant office was somewhat more externalized than that of the directors: 'That we would have synergies, we would collaborate, that is the justification I'm now starting to learn' (Interviewee 21). The employees had also been told that a shared office would be more cost effective due to, for example, shared meeting rooms. When talking about the reasons for moving to the new office, they spoke more of the explanations given to them, not of something that they really related to. One of the employees, who had only recently started in her job, said that at first, she had not known that so many different organizations would be sharing the office.

I don't know why [the organizations share the office]. I suppose it's because all these organizations work in the same region, and co-operate more or less, so it's easy being under the same roof. Perhaps that's the reason. This is only a guess. (Interviewee 11)

For many, the reasons behind sharing an office space seemed artificial, and this may have affected their attitudes towards collaboration and networking in the newly-formed work community.

\section{Adaptation - Employees' coping with the new office space and community}

This chapter brings together the interview data that describes the situation at the time of the initial interviews; the 'here and now' of the interviewees. We first consider the parts of the interview material that depict positive reception of the office and enhanced 
possibilities for collaboration. After that, we turn to the parts of data that reflect more negative thoughts on collaboration and community in the shared office.

\section{Positive responses of the office space, collaboration and community}

At the time of the interviews, many employees and managing directors had positive emotions towards the new shared office and the whole building. Besides its accessible location in the city, the office building was seen as part of the cultural heritage and the national landscape. The directors felt proud of it and saw it as having brand value. Even though the employees of the organizations had no shared history upon which to build a sense of community (see McMillan \& Chavis 1986), the history of the building provided a shared frame of reference; the building had a symbolic value for the work community. The design and atmosphere of the new office were depicted as 'awesome' and 'a stroke of luck': 'to think that we have the opportunity to be here, in an old factory in the heart of [the city], instead of working in some sterile cubicles' (Interviewee 4).

The interviews depicted overall satisfaction with the new office environment, and most had adapted quickly. Positive comments regarding the workspace and community related to both emotions and performing work tasks. The interviewees described a positive buzz at work, ease in contacting others due to the shared office and enhanced communication: 'There were also fears at the outset, but now we are closer to our partners and get information efficiently. We can discuss things without having to schedule a meeting two weeks ahead. We see the gains and benefits daily' (Interviewee 3).

Some employees embraced the opportunities for easy interaction in the shared office. Two special hubs for community building and networking were highlighted in the interviews: the shared conference center, and the recreational space. The conference center was considered a good place for networking: When meetings start and end at the same time, people are on the move, and encounters occur naturally. In addition to this, the interviewees were especially proud of the large recreational space with large windows and beautiful scenery. Employees could use the recreational space for coffee and lunch breaks as well as for informal meetings. One employee described the atmosphere and design of the space as 'breathtaking'.

Some employees felt that they had built a closer relationship with workmates sitting nearby. Some emphasized that every employee should adopt an active stance: make acquaintances and network unprompted. 'It's all about attitude. If you always sit in the same cubicle, [a shared office] makes no difference. But I am social by nature, I need people, I always talk to people, say hello. This [office environment] suits my character' (Interviewee 2).

\section{Critical thoughts about the office, collaboration and community}

In the interviews, it was nevertheless clear that the newly renovated and centrally located office building was not enough to create collaboration or a sense of community. Despite the overall satisfaction with the office, some employees were discontent with the experience of noise and lack of privacy. The interviewees reported very different experiences of noise in the office. Some felt that the office was peaceful, while others working in a similar 
environment said that they had to use hearing protectors to be able to concentrate. Longing for single rooms was a recurrent motif in the latter employees' interviews. They justified this longing with the nature of their work: Their work required intense concentration, and some also needed large computer screens and materials on paper.

At least one team had developed a strict policy of not disturbing each other by speaking unless it was absolutely necessary. The ethos of silence had become important for the team members. The newest employee in the team was somewhat confused: 'I feel it's a bit too much if you have to be really quiet. It's an open-plan office after all' (Interviewee 19). The silence policy had led the employees to communicate by email with people sitting next to them. This finding is in line with Bernstein and Turban's study of increasing electronic communication in open work environments (2018). Some of the employees in our study complained that they now had no place to go if they had to speak privately with someone - previously they had visited the other person's own office, but now they could not have conversations by each other's desks, because they worried about disturbing others. They felt that the open-plan design had destroyed informal interaction among colleagues. This result is consistent with previous studies that have shown that employees in open-plan offices report high levels of uncooperative behaviors (Morrison \& Macky 2017; Irving et al. 2019).

In previous research, the 'openness' of space has marked a prerequisite for a lively coworking community: Jakonen et al. (2017, p. 238) describe how long corridors posed a challenge to interaction in a coworking space located in a traditional corridor office, but glass windows made the rooms feel more open in a positive sense. Irving et al. $(2019,5)$ describe how the architect of a 'collaborative building' wanted a 'building without walls', using glass walls to maintain visual connections across the building. One employee in our data described how 'openness' had become a central metaphor in the design of the new office and the atmosphere it was meant to create. Some employees were critical of the metaphors of openness that the management used to describe the office space. To them, an open space with glass walls and low screens between desks did not really promote the communication and collaboration presented to them as its purpose. Våland and Georg's case study of organizational and architectural change in a municipal administration in Denmark shows a similar case of glass walls signaling 'an open, transparent and modern organization' but compromising confidentiality (Våland \& Georg 2018, p. 198).

The structures of networking actualized in the face-to-face encounters in the office space. According to the interviewees, the recreational space was slightly underutilized and perhaps even undervalued: 'Unfortunately my schedules don't permit me to spend time there' (Interviewee 27). Many employees did not take coffee breaks at all, and if they did, they did so with their closest colleagues. Many noticed that this was undesirable and hoped for a change towards a more social working culture. The recreational space was recognized as both a place for recovery during the working day and a good place for networking, but its potential was not fully realized. One of the directors summed this up: 'It's a fantastic, attractive space, but the idea of collaboration between organizations has not been realized there as expected. People from each organization clearly sit among their own folk during coffee breaks' (Interviewee 10). This kind of reinforcement of group boundaries is one of the strategies to avoid new collaborations that Irving et al. (2019, p. 12) also found in their study of an office space that was designed to promote collaboration.

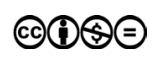


Some employees noted that people from different organizations did not even greet each other in the office:

It's a bit awkward to say hello to someone when you're not sure if they'll greet you back. Then you end up hoping that no one will appear, so that you don't have to wonder whether or not to start a conversation. (Interviewee 21)

The experience of non-encounter challenges the possibilities for building a sense of community or fostering collaboration. Irving et al. (2019, pp. 13-14) found that one strategy which employees use to avoid new collaborations is to minimize social interaction. This is done by bodily signals such as avoiding eye contact, wearing headphones or adopting postures that signal unwillingness to interact. In our case, the structure and design of the space isolated some workers into their own little 'nests' in which they aimed to protect themselves against disturbances. This territorial withdrawal can be seen as a coping strategy comparable to those measured by Kaarlela-Tuomaala et al. (2009), for example, working overtime or working more slowly. Personalizing specific desks and refusing to share office space can also be individual strategies to claim ownership of a small corner of the environment (cf. Pierce \& Jussila 2010). One of the employees compared the office to a city street, in which people pass each other by anonymously, not really encountering, not collaborating, not even knowing each other. This is a completely different metaphor to the director's image of the office as his own land, where he strolls around as he wishes.

Despite expectations, the interaction between the managing directors had not intensified in the shared office. From the beginning, each director had focused on managing their own organization with no common vision. The directors' meetings had come to a halt after a few attempts. The directors were happy to meet informally, but they recognized that these occasional encounters were, first of all, quite rare, and second, insufficient for strategic planning.

Similarly, the employees had not started co-operating more. One interviewee made an ironic point when asked about collaboration between organizations: 'Last week the fire alarm went off, so we all went out of the building together' (Interviewee 21) the interviewee could not think of any other example of collaboration. Some employees repeatedly stated that 'others' may benefit from the opportunity for closer collaboration among the organizations, but that these opportunities had no effect on their own work. In practice, a few of the interviewed employees co-operated concretely with the employees of the other organizations in the same office, but most of them did not collaborate with other organizations at all. Nevertheless, the majority longed for more community spirit and contacts between employees of different organizations. The structuring of a new work community from above (the owners' side) had not led to a sense of community among the employees of different organizations. The interviews included a great deal of discourse on what ought to be done to develop this state of affairs: there should be events that are open to all; people should communicate and interact more; people should collaborate on thematic matters; overall, they should collaborate more.

The reasons for the lack of collaboration and sense of community seem to be practical, on the one hand: The interviewees felt they did not have enough time for anything other than their own work tasks; there was no one to manage collective activities or co-operation; and this led to employees simply not knowing each other. On the other 
hand, the interviewees blamed the different working cultures of each organization. Many of them revealed an attitude that opposed cooperation or building a deeper connection with employers of other organizations. In these views, the organizations and the work tasks differed from each other to such an extent that collaboration was unnecessary: 'We're all responsible for special issues. So, we don't have much need for networking and interaction here' (Interviewee 15). One of the directors mentioned that the existing workload was a concrete obstacle to community-building events or communication between organizations: 'Our people are up to their ears in work, and they travel a lot too. I don't think they're very responsive to massive new things' (Interviewee 27). The director's viewpoint seems to partly be a value judgment regarding 'real' work on the one hand and socializing on the other hand.

Some people think that they should know everything possible, whereas I think that mostly people should concentrate on their own work. [...] If our employees have time to attend [many common events] in the long run, I say something is wrong. (Interviewee 27)

We described above how some employees felt that an open and shared working environment suits them because of their personal characteristics. In a similar way, employees who did not collaborate very much with others in the shared office said this was due to personal traits such as 'introversion'. An important finding was that in the interviews, collaboration and networking were mostly seen as being dependent on employees' personal characteristics; these practices were not managed in any way.

\section{Towards working together}

In this chapter, we present the results of the analysis of the data collected in the evaluation workshop: transcribed discussion and observation notes. In our temporal framework, these data have an emphasis on change; they consist of evaluation of the recent past and visions for future. As a general observation of these data, we first highlight a few points regarding the progression of the evaluation discussion. Regardless of what concepts were given in the evaluation framework, participants spoke about things that were important to them at that specific moment (such as the perceived lack of directors' support or the reasons for non-participation in the development workshops). They did not always stick to the given framework but utilized the evaluation workshop to resolve concrete issues such as organizing upcoming events. It seemed that in the work community, employees had no organized discussion forums for shared matters. The evaluation framework includes a part in which participants should present concrete suggestions for future development and decide who promotes each action (Hyytinen et al. 2017, p. 314). In this case, such suggestions of future actions were missing. We interpret that this was because the group simply had none. In addition, there was not enough knowledge regarding who could be entrusted with the responsibility of advancing the plans. This is both a research finding related to the situation of the studied work community, and a methodological observation concerning the evaluation framework.

According to our analysis of the data collected in the evaluation workshop, things had changed to some extent. In the evaluation workshop, one of the directors - the only 
one who attended this workshop - crystallized the desire for a new basis for the shared office's existence:

From the management's point of view, when the idea [of a shared office for these organizations] first came out, the common denominators were the owners and cost efficiency. They were the drivers. Then the idea evaporated, everyone was just happy about the new office. But during this project, a new idea has emerged, to search for a new common denominator for our collaboration. To find a new point for being here, now that common ownership alone is not enough. (Interviewee 10)

On the practical level, the employees and directors had developed several new forms of facilitating community and collaboration. A 'Well-being Group' had been established, the tasks of which were to organize bottom-up activities to enhance work-related wellbeing and generate more collaboration between organizations. The Well-being Group consisted of voluntary employees from each organization. By the time of the evaluation workshop, the Well-Being group had organized sports and after work events and decided to start a series of pitch talks open to all organizations. A series of open lectures had also been initiated, in which each organization, one after the other, invited an outside expert to lecture on a topical issue. A monthly walking event had been introduced: All employees could join an afternoon walk on a specific day to get acquainted with new people and discuss current topics. The managers had also decided to return to holding organized meetings at regular intervals.

The participants of the evaluation workshop thought that the intervention workshops had been important moments in the middle of everyday hustle and bustle. Yet, the discussion highlighted that only a small proportion of the employees -16 people had participated in the workshops aimed at promoting work-related well-being and networking. This was not many, considering that the organizations employed over 180 people at the beginning of the workshops. However, the participants came from all but one organization. In the directors' coaching workshops, it was agreed at the outset that if any of the directors were unable to participate, a deputy would take their place. This arrangement was meant to ensure continuity. Eventually, all the directors attended at least one workshop, but none engaged in all of them.

A great topic of discussion in the evaluation workshop was the small number of participants of the well-being and networking workshops. The active participants thought that the reasons for others' non-participation were a shortage of time and heavy workloads. The main reason that the participants gave for non-participants' weak involvement, however, was the perceived lack of managerial support. The employees interpreted this as directors' lack of commitment to the strategic development of the community of all the six organizations. The employees felt that promoting collaboration and community had been left to them. This feeling was further supported by the fact that only two of the directors had participated in the well-being and networking workshops, and that only one of them was present in the evaluation workshop.

The discussion in the evaluation workshop revealed a struggle over what was considered important in the work community. Taking part in well-being and networking workshops may seem lightweight compared with 'concentrating on one's own work', to use the expression of one of the directors in the interviews. During the evaluation workshop, active participants of the intervention workshops strived to legitimize their 
community-building activities as a profitable use of work time. In the participants' discourse, the community and social interaction emerged as a resource. They emphasized that they had received good tips from other organizations and learned a lot from others in the workshops. These tips and learning from others are, according to our interpretation, parts of coworking economy; commodities and gifts that coworkers exchange in interaction (Jensen 2008; Jakonen et al. 2017). In the evaluation workshop, the participants presented the idea that not only the centrally located beautiful building but also the sense of community and the 'positive buzz' could build a mutual brand of the six organizations. The evaluation framework also guides this kind of thinking using concepts such as 'economy' and 'reputation'.

The evaluation discussion highlighted that some improvements had taken place in collaboration during the intervention period. One of the participants summed up the improved sense of community: 'Before this [intervention] process, I didn't feel like we were all work mates, but now it feels like that. At least to me, because I became intensively engaged in the collective activities'. Interaction had started to lead to emotional connections with the employees of the coworking organizations, as McMillan and Chavis's (1986) theory presupposes. However, cooperation between different organizations was not yet considered sufficiently close. The conversation ended with the participants' conclusion that at the moment, people were collaborating, but the organizations were not. The employees wished for more strategic and management-led cooperation.

The evaluation workshop revealed a shared concern regarding how the improved community and collaboration would continue. The employees encouraged the directors to carry the responsibility for the strategic planning of common affairs. In addition, an idea that the organizations should report to their boards on the realization of collaboration and synergies emerged, as the owners' presumption was that a shared office would produce this. One of the final thoughts in the evaluation workshop came from one of the employees: 'We need a community manager here'. The only director present at the evaluation workshop supported the idea:

Those [coworking spaces] and platforms, they have such a facilitator. They try to maintain a community and organize things. But we don't have anything like that. We only rent the same facilities. There's no common denominator. What if all the organizations dug into their pockets, so that we could take on such a facilitator?

Sankari reviews many studies that have found community management techniques and trained staff important in providing coworking space users access to each others' skills and improving the community (Sankari 2019, pp. 3-4). The evaluation workshop helped the participants recognize that facilitating collaboration was a task in itself, and that a sense of community does not germinate spontaneously.

\section{Discussion}

Our aim in this case study was to examine how community and collaboration were understood, strived for and constructed in speech and action within a work community of six publicly owned companies that shared a multi-space office in a major Finnish city. We approached the shared office from the viewpoint of coworking ideals - community,

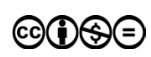


collaboration, encounters and sharing competence - claiming that these ideals also influence discourses on office spaces in bigger organizations.

Our study provides insights into the reasons why work organizations adopt shared work environments. In our case, the owners of the companies had encouraged a move to a shared office for practical reasons. The directors also strived to increase collaboration and synergy benefits that they believed would arise from the physical proximity of employees. According to earlier research, however, the impact of proximity on employees' communication and collaboration is ambiguous (Coradi et al. 2015, pp. 58-59; Irving et al. 2019, pp. 3-4). Our research setting resembles greatly that of Irving et al. (2019), who studied government employees from different organizations having been co-located in a new office environment. The vision had been quite the same as in our case: that an open environment would produce new collaborative partnerships. Irving et al. found that collaboration was rare, and identified several strategies that employees used to avoid new collaborations. An important point is that according to Irving et al. (2019), not proximity itself but employees' responses to proximity facilitates or inhibits collaboration.

In terms of collaboration and sense of community, the shared office had not delivered on its promises by the start of our research and development project. Networks had not developed between the organizations as effectively as had been hoped. Our empirical data demonstrated tensions in daily practices. The shared recreational room brought enjoyment and energy to many. In a way, it was a symbol for a boundaryless way of organizing - a space in which organizational boundaries were challenged. However, at the same time, it made them visible and showed that they remained (cf. Cohen's ideas on the significance of boundaries for communities); immediate interaction and unstructured communication did not spread to the work done in the office. It was evident that some employees had developed a mutual understanding of a 'good' office space that suited the type of work they did. A peaceful, silent environment was their shared value, and they tried to achieve this by mimicking the conditions of a cellular office, even when this was dysfunctional for their daily communication.

As we presented at the beginning of this article, research shows that coworking has several benefits for independent professionals: it can increase social support and enhance a sense of community (Gerdenitch et al. 2016; Garrett et al. 2017). It is also worth noting that popular literature tends to be overtly positive about the benefits of coworking. 'Serendipitous encounters' are supposed to be the essence of coworking. Our research supports the findings of Jakonen et al. (2017) that even in coworking spaces that are intentionally curated, these encounters do not necessarily take place. Neither do members of coworking spaces necessarily collaborate for shared work objectives (Spinuzzi et al. 2019) more than the employees in our case organizations. To continue Spinuzzi et al.'s discussion on the nature of community and collaboration in coworking, we suggest that in shared work environments (either coworking spaces of self-employers or multi-tenant offices of bigger companies), the ideal of collaboration does not necessarily manifest itself as co-laboring in mutual projects. Collaboration can also occur in the forms of small gift-giving that Jensen (2008) describes, such as inviting others to interesting events or recommending suppliers to each other. These gifts are probably given in the hope of getting a return gift, but the nature and time of that return is not easy to specify.

De Paoli et al. (2013) point out that Scandinavian offices often emphasize good work environment for employees; for example, they tend to be less dense and smaller 
than their counterparts in Central Europe or Anglo-American countries. According to a Swedish study, an activity-based working environment requires a high level of self-leadership, which may become a burden to an individual employee (Bäcklander et al. 2019). The office we studied hosted six companies that were 'traditional workplaces' with traditional managerial relationships. Based on our results, we suggest that shared work environments may mostly benefit self-employed workers and small businesses who voluntarily seek contacts with other independent professionals and gain potential business assets from networking. For employees of larger and more hierarchical organizations, these benefits may be less clear and less relevant to the nature of their work. As Bouncken and Reuschl (2018) point out, coworking space users have a high level of autonomy in terms of usage of space, communication and interaction. They may freely decide 'to take the opportunity - not the necessity - to interact with others on loose terms or very intense, to be open in job-related issues and private issues' and so forth. Coworking enables combinations of task-related and leisure targets as well as social and economic targets (Bouncken \& Reuschl 2018, p. 320). Moriset (2017) also sees coworking as a lifestyle (un style de vie). The characteristics described above do not apply to the work community we studied. Instead, in our research case, enabling collaboration and building a sense of community were seen as the responsibility of managers. When the managing directors were not active in this task, the employees took the initiative in the development workshops and established a Well-being group for promoting not only well-being at work but also other common interests.

A limitation of the study at hand is that it is based on one case. A more comprehensive study approach with a larger data would complement the findings of case studies that have been conducted in shared offices. Another limitation is that the study design did not allow follow-up; thus, we have no knowledge whether the newly formed practices to improve collaboration and community lasted after the project.

\section{Conclusion}

Our study of collaboration and community in a multi-space office shared by several organizations provides preliminary evidence of the significance of the collaborative design of work environments. Furthermore, it highlights the importance of paying attention to social factors in shared work environments. The research results indicate that a shared and open office solution does not lead to interaction and collaboration all by itself. If collaboration and community are valued in work organizations, they need to be managed and actively supported.

\section{References}

Adler, P. S. (2015). Community and innovation: from Tönnies to Marx, Organization Studies 36(4): 445-471. doi: https://doi.org/10.1177/0170840614561566.

Adler, P. S. \& Heckscher, C. (2006). Towards collaborative community. In C. Heckscher, \& P. S. Adler, eds., The Firm as a Collaborative Community: Reconstructing Trust in the Knowledge Economy, New York: Oxford University Press, pp. 11-105. 
Babapour, M., Karlsson, M. \& Osvalder, A.-L. (2018). Appropriation of an activity-based flexible office in daily work, Nordic Journal of Working Life Studies 8(S3): 71-94. doi: https://doi.org/10.18291/njwls.v8iS3.105277.

Bengtsson, M. (2016). How to plan and perform a qualitative study using content analysis, NursingPlus Open 2: 8-14. doi: https://doi.org/10.1016/j.npls.2016.01.001.

Bernstein, E. S. \& Turban, S. (2018). The impact of the 'open' workspace on human collaboration, Philosophical Transactions of the Royal Society B 373: 20170239. doi: https:// doi.org/10.1098/rstb.2017.0239.

Bouncken, R. B., Laudien, S. M., Fredrich, V. \& Görmar, L. (2018). Coopetition in coworking-spaces: value creation and appropriation tensions in an entrepreneurial space, Review of Managerial Sciences 12(2): 385-410. doi: https://doi.org/10.1007/ s11846-017-0267-7.

Bouncken, R. B. \& Reuschl, A. (2018). Coworking-spaces: how a phenomenon of the sharing economy builds a novel trend for the workplace and for entrepreneurship, Review of Managerial Sciences 12(1): 317-334. doi: https://doi.org/10.1007/s11846-016-0215-y.

Bäcklander, G., Rosengren, C., Falkman, L. L., Stenfors, C., Seddigh, A., Osika, W. \& Stenström, E. (2019). Navigating the activity-based working environment - relationships of self-leadership, autonomy and information richness with cognitive stress and performance, Scandinavian Journal of Work and Organizational Psychology 4(1): 1,1-14. doi: https://doi.org/10.16993/sjwop.58.

Capdevila, I. (2015). Co-working spaces and the localised dynamics of innovation in Barcelona, International Journal of Innovation Management 19(3): 1540004. doi: https://doi. org/10.1142/S1363919615400046.

Cohen, A. P. (1985). The Symbolic Construction of Community, London: Tavistock Publications.

Coradi, A., Heinzen, M. \& Boutellier, R. (2015). A longitudinal study of workspace design for knowledge exploration and exploitation in the research and development process, Creativity and Innovation Management 1(24): 55-71. doi: https://doi.org/10.1111/caim. 12099.

De Paoli, D., Arge, K. \& Blakstad, S. H. (2013). Creating business value with open space flexible offices, Journal of Corporate Real Estate 15(3/4): 181-193. doi: https://doi.org/ 10.1108/JCRE-11-2012-0028.

DeGuzman, G. V. \& Tang, A. I. (2011). Working in the 'Unoffice': A Guide to Coworking for Indie Workers, Small Businesses, and Nonprofits, San Francisco: Night Owls Press.

Erlingsson, C. \& Brysiewicz, P. (2017). A hands-on guide to doing content analysis, African Journal of Emergency Medicine 7(3): 93-99. doi: https://doi.org/10.1016/j.afjem. 2017.08.001.

Gandini, A. (2015). The rise of coworking spaces: a literature review. Ephemera 15(1): 193-205. Available at: http://www.ephemerajournal.org/contribution/rise-coworkingspaces-literature-review [Accessed August 6, 2019].

Garrett, L. E., Spreitzer, G. M. \& Bacevice, P. A. (2017). Co-constructing a sense of community at work: the emergence of community in coworking spaces, Organization Studies 38(6): 821-842. doi: https://doi.org/10.1177/0170840616685354.

Gerdenitsch, C., Scheel, T. E., Andorfer, J. \& Korunka, C. (2016). Coworking spaces: a source of social support for independent professionals, Frontiers in Psychology 7: 581. doi: https://doi.org/10.3389/fpsyg.2016.00581.

Gerring, J. (2007). Case Study Research: Principles and Practices, Cambridge: Cambridge University Press.

Graneheim, U. H., Lindgren, B.-M. \& Lundman, B. (2017). Methodological challenges in qualitative content analysis: a discussion paper, Nurse Education Today 56: 29-34. doi: https://doi.org/10.1016/j.nedt.2017.06.002. 
Houni, P., \& Ansio, H. (2015). Coworking spaces - creative sparks in the urban milieu, Helsinki Quarterly 2015(3): 10-21. Available at: https://www.kvartti.fi/en/articles/coworking-spaces-creative-sparks-urban-milieu [Accessed November 11, 2019].

Huwart, J.-Y., Dichter, G. \& Vanrie, P. (2012). Coworking: Collaborative Spaces for Microentrepreneurs. Available at: http://ebn.be/downloads/coworking\%20technicalnotes. pdf [Accessed August 6, 2019].

Hyytinen, K., Saari, E., Leväsluoto, J., Hasu, M., Käpykangas, S., Melkas, H., Pekkarinen, S., Hyypiä, M., Korvela, P., Nordlund, A., \& Toivonen, M. (2017). Human-centered coevaluation method for digital service innovations. In E. Hernandez, D. Sanchez, S. Arando \& M. Tkacz, eds., Proceedings of the 27th RESER Conference Bilbao Sep 7-9, 2017. Bilbao: Mondragon Unibertsitatea, 304-325. Available at: http://reser2017.com/wp-content/uploads/2017/10/RESER\%202017 Proceedings.pdf [Accessed August 6, 2019].

Irving, G. L., Ayoko, O. B. \& Ashkanasy, N. M. (2019). Collaboration, physical proximity and serendipitous encounters: avoiding collaboration in a collaborative building, Organization Studies (advance online publication). doi: https://doi.org/10.1177/ 0170840619856913.

Jakonen, M., Kivinen, N., Salovaara, P. \& Hirkman, P. (2017). Towards an economy of encounters? A critical study of affectual assemblages in coworking, Scandinavian Journal of Management 33(4): 235-242. doi: http://dx.doi.org/10.1016/j.scaman.2017.10.003.

Jensen, T. E. (2008). Experimenting with commodities and gifts: the case of an office hotel, Organization 15(2): 187-209. doi: https://doi.org/10.1177/1350508407086578.

Kaarlela-Tuomaala, A., Helenius, R., Keskinen, E. \& Hongisto, V. (2009). Effects of acoustic environment on work in private office rooms and open-plan offices - longitudinal study during relocation, Ergonomics 52(11): 1423-1444. doi: https://doi.org/10.1080/ 00140130903154579.

Kim, J., Candido, C., Thomas, L. \& de Dear, R. (2016). Desk ownership at the workplace: The effect of non-territorial working on employee workplace satisfaction, perceived productivity and health, Building and Environment 103: 203-214. doi: https://doi. org/10.1016/j.buildenv.2016.04.015.

Kojo, I., \& Nenonen, S. (2016). Typologies for co-working spaces in Finland: what and how? Facilities 34(5/6): 302-313. doi: https://doi.org/10.1108/F-08-2014-0066.

McMillan, D. W., \& Chavis, D. M. (1986). Sense of community: a definition and theory, Journal of Community Psychology 14, 6-23.

Moriset, B. (2017). Inventer les nouveaux lieux de la ville créative: Les espaces de coworking [Building new places of the creative city: the rise of coworking spaces], Territoire en mouvement Revue de géographie et aménagement 2017(34). doi: https://oi.org/10.4000/ tem.3868.

Morrison, R. L. \& Macky, K. A. (2017). The demands and resources arising from shared office spaces, Applied Ergonomics 60: 103-115. doi: https://doi.org/10.1016/j.apergo.2016.11.007.

O'Reilly, K. (2005). Ethnographic Methods, London: Routledge.

Pierce, J. L. \& Jussila, I. (2010). Collective psychological ownership within the work and organizational context: Construct introduction and elaboration, Journal of Organizational Behavior 31(6): 810-834. doi: https://doi.org/10.1002/job.628.

Pierce, J. L., Kostova, T. \& Dirks, K. T. (2001). Toward a theory of psychological ownership in organizations, Academy of Management Review 26(2): 298-310. doi: https://doi. org/10.5465/amr.2001.4378028.

Sankari, I. (2019). Co-working Space as Workplace: Characteristics and User Experience, Helsinki: Aalto University.

Saval, N. (2014). Cubed: A Secret History of the Workplace, New York: Doubleday. 
Sennett, R. (2012). Together: The Rituals, Pleasures and Politics of Cooperation, London: Allen Lane.

Sirola, P., Ruohomäki, V. \& Lahtinen, M. (2017). Yliopiston henkilöstön työn sisällöt ja kokemukset uudistuneesta työympäristöstä [University employees job content and experiences of new working environments], Psykologia 52(1): 4-22. Available at: http://www. psykologia.fi/arkisto/vanhat-numerot/vanhat-numerot-ghost/471-2017-01/tieteelliset-artikkelit/596-yliopiston-henkiloston-tyon-sisallot-ja-kokemukset-uudistuneesta-tyoymparistosta [Accessed August 6, 2019].

Spinuzzi, C. (2012). Working alone together: coworking as emergent collaborative activity, Journal of Business and Technical Communication 26(4): 399-441. doi: https://doi.org/ 10.1177/1050651912444070.

Spinuzzi, C., Bodrožić, Z., Scaratti, G. \& Ivaldi, S. (2019). 'Coworking is about community': but what is 'community' in coworking? Journal of Business and Technical Communication 33(2): 112-140. doi: https://doi.org/10.1177\%2F1050651918816357.

Sutela, H. \& Pärnänen, A. (2018). Yrittäjät Suomessa 2017 [Self-employed persons in Finland 2017], Helsinki: Tilastokeskus.

Våland, M. S. \& Georg, S. (2018). Spacing identity: unfolding social and spatial-material entanglements of identity performance, Scandinavian Journal of Management 34(2): 193-204. doi: https://doi.org/10.1016/j.scaman.2018.04.002.

Yin, R. K. (2018). Case Study Research and Applications: Design and Methods (Sixth edition), Los Angeles: Sage. 